\title{
TITLE:
}

\section{Electron cooling of hot ion beams( Abstract_要旨)}

\author{
AUTHOR(S):
}

Fadil, Hicham

CITATION:

Fadil, Hicham. Electron cooling of hot ion beams. 京都大学, 2005, 博士 (理学)

ISSUE DATE:

2005-03-23

URL:

http://hdl.handle.net/2433/145083

RIGHT: 


\section{氏 名 FADIL HICHAM}

学位(専攻分野) 博士 (理 学)

学 位記 番号 理 博 第 2873 号

学位授与の日付 平 成 17 年 3 月 23 日

学位授与の要件 学 位 規 則第 4 条第 1 項 該 当

研究科. 専攻理学研究科物理学. 宇宙物理学専攻

学位論文題目 Electron Cooling of Hot Ion Beams

（電子ビーム冷却法を用いた高温イオンビーム冷却）

論文調査委員教授野田章教授今井憲—教授笹尾登

\section{論文 内 容の 要旨}

ビームの品質は位相空間内の体積であるエミッタンスで記述できるが, 電磁場のような保存力の場のみによっては, Liouvilleの定理により，エミッタンスは変化しない。反陽子の生成や大電力レーザーによる薄膜からのイオンビーム生成 といった生成 2 次ビームをハンドリングする際には，イオン光学要素のサイズの軽減の必要性から，ビームを「冷却」する ことによりエミッタンスの縮減を図ることが本質的重要性を有する場合が多い。イオンビームの冷却法として，確立してい る手法としては，確率冷却，電子ビーム冷却，レーザー冷却が挙げられるが，レーザー冷却は使用可能なレーザーの波長の 制約から，適用できるイオン種が限られており（現在までに実証されているイオンビームは ${ }^{7} \mathrm{Li}^{+},{ }^{9} \mathrm{Be}^{+},{ }^{24} \mathrm{Mg}^{+}$の 3 種類の み）一般的な使用は困難であり，イオン全般にわたる冷却法は確率冷却と電子ビーム冷却に限られる。従来，電子ビーム冷 却は電子ビームのイオンビームとの相対速度が大きくなると長距離にわたる並進が困難となるため，冷却力の有効領域が狭 く，確率冷却に比して高温のイオンビームの冷却には適さないというのが通説であった。

本研究はこうした通説に対し，イオンビームと電子ビームの相対速度を掃引することにより，冷却力の有効領域にイオン ビームを積極的に持ち込むことにより，電子ビーム冷却を高温のイオンビームに対しても有効に作用させる可能性に挑んだ ものである。ドイッハイデルベルグのマックスプランク原子核研究所のイオン蓄積・冷却リング TSRを用いて，イオンビ 一ムと電子ビームの相対速度を掃引した場合の電子ビーム冷却力の変化について実験的に測定を行っている。具体的には

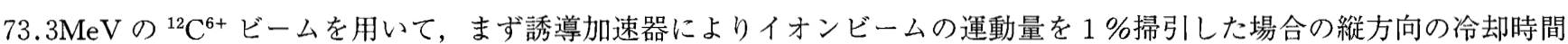
を測定し，誘導加速を行わない場合の 2.9 秒が $0.4 \mathrm{~V}$ の誘導加速により，0.65秒まで短縮されるという実験結果を得ている。 このスキームにおいては, 誘導電圧が大きいほど冷却時間が短縮されることが確認されているが, イオンビームの電子ビー ム冷却力によるキャプチャーの取りこぼしを防ぐためには，印加可能な最大誘導電圧は，電子ビーム冷却力のキャプチャー ポテンシャルに比して低く抑える必要があることも確認された。ついで，イオンビームのエネルギーを固定し，電子ビーム 加速のための高電圧を掃引する場合に関しても実験を行い，電子銃のカソード電圧とアノード電圧の差で決定される電子ビ 一ムエネルギーを，電子銃のカソード電圧を徐々に変化させ， $1 \%$ の入射ビームの運動量幅にわたって電子ビーム冷却力を スイープすることにより，73.3 MeVの炭素 6 価イオンを 0.35 秒で $0.1 \%$ まで冷却可能であることを示し，前述の通説が普 遍的に当てはまるものでないことを立証した。両者の手法の到達冷却時間の間には0.65秒と0.35秒という差が存在するが， これはTSR で使用可能な誘導電圧が $0.4 \mathrm{~V}$ までに限られているという事情によっている。電子ビームのエネルギースイー

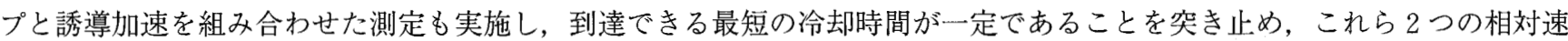
度掃引の手法が物理的には等価であることを示している。

本研究は上述の縦方向のイオンと電子の相対速度を掃引することにより，電子ビーム冷却力の有効領域にイオンビームを 持ち込むという手法が，横方向のビーム冷却もより効率化出来ることも実証している。誘導加速によるイオン速度の掃引及 び電子エネルギーの掃引のいずれの場合にも，通常の電子ビーム冷却の横方向冷却時間が 4 秒程度であるのを 1 秒程度まで 
ファクター 4 程度短縮可能であることを実験により示している。

\section{論 文 審 查 $の$ 結 果 $の$ 要 旨}

申請者は生成 2 次粒子ビームのような運動量拡がりの大きなイオンビームの冷却に関して,「電子ビーム冷却は冷却力の 有効な領域が $\pm 0.1 \%$ 程度と限られており，確率冷却に比して高温のイオンビームの冷却には適さない。という従来の通説 に対し, イオンビームと電子ビームの相対速度を掃引することで, 電子ビーム冷却の冷却力が有効な領域にイオンビームを 強制的に持ち込むことにより，冷却の効果を高める可能性に注目し，その原理実証を進めてきた。実験はドイツハイデルベ ルグのマックスプランク原子核研究所に既存のイオン蓄積・冷却リング TSR とその電子ビーム冷却装置を活用し，73.3 $\mathrm{MeV}(6.1 \mathrm{MeV} / \mathrm{u})$ の 6 価の炭素イオンに対して行われている。

イオンビームと電子ビームの相対速度を掃引する具体的な方法として，まず電子ビームのエネルギーを固定し，イオンの エネルギーをTSR 中に設置されている誘導加速装置を使用して加・減速を行うことにより変化させる手法についてテスト を行い, 縦方向の電子ビーム冷却時間は, 誘導加速電圧の増大と共に短縮されることを確認し, 中心の運動量より $1 \%$ 低い 炭素イオンを中心まで電子ビーム冷却により移動させる時間が, こうした誘導加速を行わない通常の場合の 2.9 秒に対して, 最大の $0.4 \mathrm{~V}$ を印加した場合 0.65 秒まで短縮可能であることを示している。

次に, 申請者はイオンビームのエネルギーを固定して, 電子ビームのエネルギーをスイープすることにより，相対速度を 変化させる手法に関しても研究を行い，電子銃のアノード電压を固定して，カソード電圧を徐々に変化させることにより電 子ビームのエネルギーを $1 \%$ の入射イオンビームの運動量幅全域にわたってスイープすることにより，0.35秒で運動量幅を $0.1 \%$ \%縮減できることを示している。

申請者は以上の $2 つ 0$ 手法が物理的に等価であることを電子ビームエネルギースイープと誘導加速を組み合わせた測定に より示し, 両者の冷却時間0.65秒と0.35秒の差は, TSR で使用可能な誘導加速装置の最大電圧が $0.4 \mathrm{~V} と$ 制限されている ことに起因しており，本質的には両者は等価であることを明らかにしている。

また, 以上の縦方向の相対速度の掃引により横方向の電子ビーム冷却力も効率化されることに気づき, 軌道の運動量分散 が小さく $($ - 1 cm) 運動量の拡がりによるビームサイズの拡がりが, エッミタンスによる拡がりに比して無視しうるリング 中の直線部に設置されたビームプロファイルモニターを用いた測定により, 横方向の電子ビーム冷却時間もファクター 4 程 度短縮されることを実験的に示している。

本研究は日独の複数の研究者との共同研究で行われているが, 申請者はドイッのマックスプランク原子核研究所の TSR の制御系について，共同研究者の Grieser 博士を介して熟知したうえで，日本に於いて必要とされる制御の更新を企画し， 必要な回路系を日本から実験に先立ち送付する等実験のハードウエアの面でも主体的に実験を毫引すると共に，電子ビーム 冷却過程に対するコンピューターシミュレーションも積極的に遂行し，夆験計画の策定も常に主体的に行ってきており，本 研究は申請者の寄与なしに遂行することは不可能であったと断言できるほどの大きな寄与を果たしている。

申請者を中心とする本研究により，従来の「電子ビーム冷却は，冷却が有効に作用する領域は相対速度が士0.1\%程度の 狭い領域に限られ，高温イオンビームの冷却には適さない」という通説は，普遍的なものではないことが示され，反陽子や レーザー生成イオンビームの効率的収集に適用する可能性が示され世界的にも注目されている。よって，本論文は博士 (理学) の学位論文として価值あるものと認める。また, 論文内容とそれに関連した事項について試問を行った結果, 合格 と認めた。 